\title{
SHAREHOLDER ACTIVISM AND INTERNATIONALIZATION IN THE FAMILY FIRM
}

\author{
Alfredo M. Bobillo ${ }^{1}$, Juan A. Rodríguez-Sanz ${ }^{2}$, Fernando Tejerina-Gaite ${ }^{3}$ \\ Department of Economics and Business, University of Valladolid, \\ Campus Miguel Delibes, 47011 Valladolid, Spain \\ E-mails:11amartbob@eade.uva.es (corresponding author); \\ 2jantonio@eco.uva.es; ${ }^{3}$ tejerina@sid.eup.uav.es
}

Received 09 June 2011; accepted 26 June 2012

\begin{abstract}
We present the internationalization of the family firm (FF) as a corporate growth strategy that is sometimes necessary to ensure survival. The different generations running the family firm (GFF) are likely to be constrained, not only by the demands of the business itself, but also by activism from non-management family shareholders. In this paper, we perform an analysis of a sample of Spanish family firms, both domestic and multinational, for the period 2000-2009. The results of this analysis show evidence of a positive relationship between the scope of internationalization and two other variables: family activism (FAI) and life cycle duration of the family firm (DLFF). When it comes to seeking alternative ways to create economic value and obtain debt finance, each generation is less risk averse than the preceding one. However, increasing family conflict over successive generations instigates economic value-destroying behavior. Overall, our findings suggest that economic value creation, leverage and international diversification in FFs will be conditioned not only by the ownership structure and size of the company, but also by the firm's current point in the business life cycle, the generation that is in charge, and activism from other family members, all of which play a decisive role in the $\mathrm{FF}$ internationalization and economic value creation process.
\end{abstract}

Keywords: shareholder activism, internationalization, family firm, economic value creation, leverage.

Reference to this paper should be made as follows: Bobillo, A. M.; Rodríguez-Sanz, J. A.; Tejerina-Gaite, F. 2013. Shareholder activism and internationalization in the family firm, Journal of Business Economics and Management 14(5): 867-885.

JEL Classification: M10, M19, G23, G32.

\section{Introduction}

Traditional theory views firm internationalization as a multiphase process starting relatively late in the business life cycle. According to some studies, internationalization is less likely to developing the early stages of the business life cycle (Eriksson et al. 1997; Johanson, Vahlne 1977). However, other studies suggest that early entry into foreign markets is generally seen as an opportunity for firm growth, particularly in dynamic, high-tech industries (Zahra et al. 2000). 
Between these two perspectives, which are not completely contradictory, we propose another. Certain characteristics of family firms (FFs), such as their ownership structure, their long-term objectives, their prioritization of survival over the exploitation of growth options, their tendency to minimize risk of going on foreign market adventures, etc., might differentiate them in behavioral terms from non-family firms, in issues related to internationalization (the scope or scale of international diversification), economic value creation and debt policy.

Specific characteristics related to ownership structure, shareholder activism, and generation running the firm (GFF), may have a decisive influence in the international diversification process of family firms. Ownership structure plays a major role both in the firm's strategic orientation and its ability to adapt to environmental change and uncertainty (Peng et al. 2004).

With regard to the influence of the generation running the company, it should be noted that the impact of this factor will depend on the stage the FF has reached in its lifecycle. Capabilities and resources for internationalization will be greater in later stages of the business lifecycle. The GFF will also assess the firm's attainable growth options against its chances of survival (Carr et al. 2010).

Another of the important factors this paper aims to analyze is the FF's economic valuecreating capability. Commenting on this point, Berle and Means (1932) note that ownership concentration reduces owner-manager conflict of interests and improves economic value-creation. Demsetz (1983) argues, in contrast, that ownership concentration is an endogenous variable deriving from the outcome of profit-maximizing decisions taken by current and future shareholders and has no impact on firm value.

In the FF environment, potential activism by certain members of the GFF not directly involved in managerial decisions can have a major impact on the firm's capacity for economic value creation and its debt policy. In this case, the major family shareholders will have greater incentives to control firm management than to expropriate wealth from minor shareholders. Within this same context, a high debt level in a FF is seen as a threat to the firm's survival and will therefore be closely monitored by non-management family shareholders.

These arguments prompted us to investigate whether there are any distinguishing features between family and non-family firms that might influence the internationalization and economic value creation process. In particular, what problems confront the family firm with respect to its growth and international diversification policy? Is there any reason to suppose that shareholder activism influences the debt, liquidity/leverage and internationalization policy of the FF? What impact does the generation running the company $^{1}$ (1GFF, 2GFF, 3GFF, etc.) have on decision-making in the family firm? Which drivers of economic value creation do family firms apply?

\footnotetext{
${ }^{1}$ For this research, a $1 \mathrm{GFF}$ is defined as a family-owned and managed firm, with more than one family member involved, but only of the first and founding generation of the family. 2GFF and 3GFF are defined as firms in which the second or third generations of the family are also involved in the ownership and management of the company (Lussier, Sonfield 2010; Leach, Bogod 1999).
} 
Our study therefore contributes in various ways to clarifying issues regarding the role of family firms. The first contribution is towards identifying drivers of the FF internationalization process, which we find to be ownership activism, the generation running the firm, and DLFF. Secondly, to highlight the importance of two factors: the firm's capacity to innovate and the issue of which generation is in charge in influencing a firm's decision-making in relation to economic leverage and value creation. Finally, we present a model to illustrate the influence of activism by non-management family shareholders in these two areas.

The remainder of the paper is organized as follows. Section 2 presents a review of the latest ideas on ownership structure, debt, economic value creation and internationalization, and a set of derived hypotheses. Section 3 shows a description of the database and methodology used in the analysis. Section 4 explains the results and examines their robustness. Section 5 discusses the findings and section 6 indicates the limitations and suggests some directions for future research.

\section{Literature review and hypotheses}

Despite the significant contribution to national economies made by family firms in terms of economic value added and employment, few countries have made precise evaluations of this impact. Another important issue to be considered is the concentration of family firms across sectors. Basically, the highest concentrations are found among small and medium enterprises (SMEs) and in traditional labor-intensive (Villalonga, Amit 2008), cyclical sectors (Bobillo et al. 2013). FFs are less likely to be engaged in financial and high-tech industries.

Another important question concerns the characteristics of the generation running the firm and the differences and similarities of its members. Most of the research points to major differences between 1 GFF and subsequent generations, although they decline with each successive generation. Dyer (1988) notes a paternalistic management culture in 1GFFs, while next generations adopt a more professional management approach.

Also worth noting in this respect is the key role played by the founder while he/she retains his/her position in the family firm, since the norms and values established by this person in the initial stages will influence the FF's structure to some extent for generations to come ${ }^{2}$. Furthermore, Moreno et al. (2010) signal the founder's orientation towards success and training for the professional qualifications as factors affecting firm size.

Following Ansari and Bell (1991) our joint technical-rational and collectivist approach to the analysis of the FF enables us to consider the possibility that the differences in organizational structure (shared values and behavioral norms) between the FF (tradition, securing independence, retaining long-term control) and the non-FF (maximization of firm value for shareholders), may result in different strategic aims with respect to economic value creation.

\footnotetext{
${ }^{2}$ Burkart et al. (2003) point out certain peculiarities that arise following the retirement of the founder in FFs in various economies.
} 
Key factors requiring consideration are the issue of which generation is in charge of the firm at any given moment and activism on the part of non-management family shareholders. As the family increases in complexity with successive generations, the management team will perceive more risk factors and seek information relating to the market, to customer needs, or to the firm's internal relations, in order to reorganize and gather the necessary resources to deal with possible market threats and exploit market opportunities. The prevailing gap between real and perceived risk creates a barrier to economic value creation in the family firm. As product/market knowledge-information (economic value creation) starts to outweigh the perceived risk deriving from the complexities of family conflict (economic value destruction) shareholders' propensity to attain higher economic value creation will increase (Fig. 1). The sooner the firm attains this objective, the sooner it will reach the stage of firm maturity and the longer it will survive in foreign markets.

In the current era of globalization with its emphasis on the trade-off between risk and profit, economic value creation in the family firm rests on four foundational pillars, namely, the ability of successive generations of management (1) to reconcile business and family goals; (2) to keep international diversification ${ }^{3}$ as a basic strategic objective; (3) to ensure the profitability of investments to strengthen the FF's chances of survival; and (4) to confront risk deriving from the capital structure of the firm, mainly through greater reliance on debt financing. These constitute the necessary drivers of economic value creation in the family firm: ownership concentration, debt capacity, current point in the business life cycle, international diversification, size, and potential for investment and growth.

The above considerations explain the internationalization of FF, which may be their way of responding to competitive pressures affecting the firm and its environment. These include the need to seek foreign investment and growth opportunities, respond

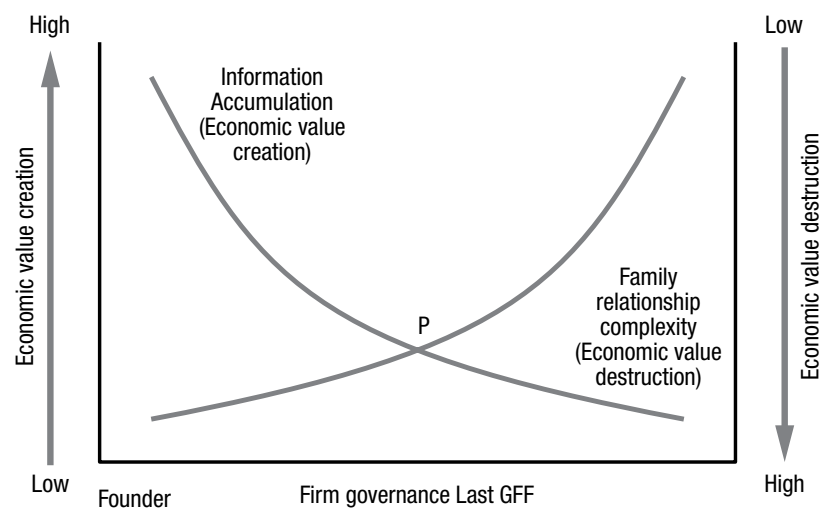

Fig. 1. Family firm governance (GFF), economic value creation and internationalization

\footnotetext{
${ }^{3}$ The terms "international diversification" and "internationalization" will be used indistinctly throughout this paper.
} 
to domestic market saturation and threats from globalization, extend the business lifecycle by expanding into foreign markets, access external knowledge and technology in order to become more competitive, and develop alliances with foreign FF in order to achieve the critical mass it takes to maintain a sufficient level of R\&D. They may also be driven by internal pressures, such as the need to create more job opportunities for family members or provide its younger members with opportunities to gain international business experience.

In the context of the internationalization of the family firm, it should be noted that the traditional theory recommends gradual development in order to acquire knowledge and experience while reducing perceived risk. It also points to the dangers to firm survival resulting from premature internationalization (Eriksson et al. 1997; Johanson, Vahlne 1977). This approach, however, has not proved entirely satisfactory in explaining cases such as the internationalization of SMEs (the category to which the majority of family firms belong) (Crick, Jones 2000). In conclusion, the incremental or gradual model fails to explain satisfactorily why some firms go international and others do not, or why some SMEs, FFs among them, interrupt their internationalization process while others accelerate theirs. Taking into account the above arguments, we focus our analysis on the internationalization of the family firm in relation to variables such as the generation running the business, the stage reached in the business cycle of the family firm (DLFF), and the potentially different goals of the members of the firm's ownership structure.

Another variable with the potential to explain family firm internationalization is CEO and TMT (Top Management Team) characteristics. Westhead et al. (2001) reported that firms with older management teams, greater resources, more information, wider contact networks and more accumulated knowledge showed a greater propensity to diversify their production internationally, especially in sectors characterized by a greater need of specific knowledge and international experience. Foreign expansion of FFs is likely to be driven by activism on the part of the various non-management ownership groups ${ }^{4}$. Control over management will increase as shareholder activism intensifies. The point will come when management will try to escape it by turning to foreign markets ${ }^{5}$, among other reasons because of differences in the risk factors perceived by insider shareholders (owner-managers) and outsider shareholders. Therefore, a higher level of family shareholder activism, an accumulated knowledge stock, a sufficient volume of resources and greater management experience are key elements in increasing the scale

\footnotetext{
${ }^{4}$ Although in the Family Activism formula developed in the methodology section we made no distinction between FF shareholder types, it is necessary to point out the differences between independent family firm shareholders (those whose only tie with the family business is their share in the capital, who are less risk averse and whose focus is on long-term objective oriented towards the firm's survival) and leveraged FF shareholders (those with vital ties to the FF, either as employees or service providers, and whose focus is on short-term objectives oriented towards firm growth and characterized by risk aversion).

${ }^{5}$ Nevertheless shareholders not involved in management may, through their greater propensity towards activism, drive the firm towards international diversification, it should be noted that they will have greater exposure to agency costs, due to the increased difficulty of controlling operations in foreign markets (Fatemi 1984).
} 
or scope of international diversification (Madsen, Servais 1997). The generation running the family firm ages alongside the firm itself and the age of either is a good predictor of international diversification.

Furthermore, various studies highlight the relationship between the characteristics of a firm's upper echelon and its organizational strategies and performance. In particular, there is evidence to show that TMT job-related diversity is linked to firm internationalization (Lee, Park 2006), while TMT diversity in age, tenure, and education are related to organizational innovations (Camelo-Ordaz et al. 2005) and to changes in corporative strategy (Wiersema, Bantel 1992).

Overall, we share the view that it is the combination of managerial ideals and family values which defines the direction of the internationalization process in FF. Based on the above arguments, we propose the following hypothesis:

H1: The scope of international diversification will be positively related with the Family Activism Index and the age of the generation running the firm.

Family firms vary in size and ownership structure, the majority being privately owned. A large proportion of the research reports that the most powerful enablers of economic value creation for FFs are the development and leverage of intangible assets - social capital, trust, reputation, and tacit knowledge. By using their capabilities and tacit knowledge, the human resources of the family firm will try to exploit market opportunities (Sirmon, Hitt 2003). In this regard, higher ownership concentration might help to minimize agency costs between owners and managers and create a family firm structure that will stimulate the capacity to exploit its fixed assets in order to pursue increased economic value creation (Gosselin 1997).

Likewise, economic value creation in the FFs may also depend on the stage reached in the business cycle. Firms reaching the end of the maturity stage will be less prone to implement new technology or exploit their innovation capabilities, and be more rigid in the style and effectiveness of their corporate governance. At the same time, as the lifecycle progresses, FFs become more conservative and less inclined to take the risks involved in business activities that might undermine the economic value creation process (Zahra 2005). In this same vein, Moreno and Castillo (2011) report an inverse relationship between firm growth and age, which might induce a negative relationship between DLFF and economic value creation.

Stability is a primary objective in FFs, where it is a higher priority than growth, which is pursued with a certain degree of caution (Upton et al. 2001). They will therefore try as far as possible to avoid risky financial operations that could have disastrous consequences for the family itself. We might also mention that the longer lifecycle of family firms, both domestic and multinational, enables them to build up a closer relationship with creditors, and thus obtain credit more easily and cheaply.

Thus, in relation with FF innovation capabilities and DLFF, the following hypotheses are proposed for testing:

H2: Ownership concentration and innovation capacity relate positively to leverage and economic value creation in family firms (both domestic and multinational). 
H3: The length of the firm's lifecycle will relate negatively to economic value creation and positively to leverage in family firms (both domestic and multinational).

Ownership concentration can play an effective role in controlling the agency problems arising from discrepancies between risk-bearers and decision-makers (Shleifer, Vishny 1997). However, the concentration of votes in large-block family shareholders is only a partial indicator of the influence of firm ownership structure, since family shareholder power increases with the frequency with which their votes leads to into decisive changes (Alchian, Demsetz 1972) and with the intensity of family activism displayed by the owners. Thus, some institutional investors and family blockholders have gained power by increasing their activism (David et al. 2001). Nevertheless, the consolidation of this group of shareholders could have major repercussions for the FF, since different shareholders may pursue different objectives (Thomsen, Pedersen 2000). Thus, family activism will relate positively to debt financing and economic value creation only in so far as the interests of large family blockholders coincide with those of minority shareholders.

Meanwhile, it is worth noting that numerous studies stress the influence of the capabilities and motivations of the firm founders (1GFF) on their successors in terms of culture, values and economic value creation in the FF (Sharma, Rao 2000). Major problems can occur if the FF succession means selecting new managers from a small, uncompetitive set of candidates from the next generation. Adams et al. (2004) note that FF governance can influence economic value creation capacity in very different ways, depending on whether the founders or their descendants are running the business. In this regard, Lentz and Laband (1990) point out the importance of the intergenerational transfer of fixed assets. Dunn and Holtz-Eakin (2000) also underline the importance of the transfer of specific capital and capabilities (decisiveness in exploiting growth opportunities and innovation) for the successful transfer of the FF to the next generation.

At the same time, the dynamics of FF succession increase the likelihood of conflict and disagreement among family members (Björnberg, Nicholson 2007). The intensity of the conflict increases with each intergenerational transfer (Beckhard, Dyer 1983). The consequence of this is the formation of groups of family shareholders who work to increase the pressure of their activism ${ }^{6}$ on the firm's managers.

Another point worth noting is that successive generations tend towards more professional, less paternalistic styles of management and financing (Lane et al. 2006). This tends to reduce debt-related risk aversion while promoting economic value creation in the firm.

These arguments lead to the hypothesis that:

H4: The degree of family activism strengthens the positive effect of ownership concentration and the incentives (of shareholders and management) to exploit innovation capabilities and growth opportunities on leverage and economic value creation in FFs.

\footnotetext{
${ }^{6}$ To assess the intensity of this activism, it is necessary to know some details of the type of ownership displayed by the family members: leveraged ownership (involving participation in the goods and/or services of the FF) or non-leveraged ownership (a share only in the capital). Other useful information relates to the situation of the owner-manager (major or minor shareholder).
} 


\section{Data and methodology}

\subsection{Data}

The sample uses individualized data for private firms in various sectors of the Spanish economy. These data, which were drawn from the Amadeus database, Actualidad Económica, España 25.000 database ${ }^{7}$ published by the organization Fomento de la Producción, and firm Web pages, cover a period running from 2000 to 2009 (7,380 observations in total). The distribution of the sample in terms of the family/non-family and domestic/multinational nature of the firm, Family Activism Index, is given in Table 1. The distribution of the sample are uniform in term of sectors of activity, however a major concentration of FF in traditional labor-intensive and cyclical industries are observed. As shown, the initial sample is comprised of 338 firms for each of the periods considered (3,380 firm-year observations).

Table 1. Sample distribution

\begin{tabular}{lccccc}
\hline & Total N. Firms & \multicolumn{2}{c}{ Family Firms } & \multicolumn{2}{c}{ Family Firms } \\
\hline FIRMS & & Multinational & Domestic & High FAI & Low FAI \\
\hline N. firms & 338 & 177 & 161 & 212 & 126 \\
\hline N. observations & 3380 & 1770 & 1610 & 2120 & 1260 \\
\hline
\end{tabular}

Note: FAI $=$ Family Activism Index.

Of the 338 family firms, 177 (52.3\%) are multinationals, while 161 (47.7\%) are domestic. Family activism is high in 212 firms (62.7\%) and low in the remaining $126(37.3 \%)$. The coefficients of correlation between the variables do not show multicollinearity. Table 2 presents the descriptive statistics.

Table 2. Descriptive statistics

\begin{tabular}{lccccc}
\hline & mean & sd & min & max & medium \\
\hline 1 lev & 0.60 & 0.22 & 0 & 1.99 & 0.61 \\
\hline 2 roa & 0.06 & 0.08 & -0.78 & 1.61 & 0.05 \\
\hline 3 c5 & 0.70 & 0.39 & 0 & 1 & 0.97 \\
\hline 4 nLSALES & 10.83 & 2.08 & 1.77 & 16.70 & 11.17 \\
\hline 5 inCSALES & 0.32 & 5.09 & -0.98 & 185.93 & 0.07 \\
\hline 6 pintang & 0.05 & 0.09 & 0 & 0.86 & 0.02 \\
\hline 7 DLFF & 3.47 & 0.56 & 1.39 & 4.76 & 3.53 \\
\hline 8 EP & 5.64 & 222.99 & -1605.88 & 10237.95 & 0.57 \\
\hline 9 IO & 16.24 & 282.90 & 0.05 & 8740.83 & 0.96 \\
\hline 10 FAI & 0.64 & 0.32 & 0 & 1 & 0.66 \\
\hline
\end{tabular}

${ }^{7}$ España 25000 is a financial database that covers the 25000 largest Spanish firms. 


\subsection{Variables}

Using this sample and following the procedure outlined in the theory section, we undertake a three-phase study. We first divide the sample FFs into two subsamples: domestic and multinational. We then sort the firms by their degree of family activism (high or low). To construct the family activism index, we need to consider not only the proportion of shares held by family shareholders, but also which generation runs and owns the business. It is the median of this index that is used to obtain the classification of the sample, which is analyzed in the third phase of the study. The family activism index (FAI) is calculated from the following expression ${ }^{8}$ :

$$
\mathrm{FAI}=\mathrm{FDI}+0.1(\mathrm{GFF}-1) I_{\left\{C_{f} \geq 10\right\}},
$$

where the first term of the above equation, FDI (Family Dominion Index), varies as a function of ownership concentration (C) and takes the following form:

$$
\mathrm{FDI}=\frac{1}{0.2} C \cdot I_{\{C f<10\}}+\left(0.5+\frac{0.4}{0.9}(C-0.1)\right) I_{\{C f \geq 10\}},
$$

where $I_{\left\{C_{f}<10\right\}}$ is a dummy variable that takes a value of 1 when family shareholders hold less than $10 \%$ of the shares and 0 otherwise, and $I_{\{C f \geq 10\}}$ is a dummy variable that takes a value of 1 when family shareholders hold $10 \%$ or more of the shares and 0 otherwise. This expression represents a linear interpolation, such that FDI has a value of 0 when $C$ equals zero, 0.5 when $C$ is $10 \%$ and 0.9 when $C$ is $100 \%$.

The second term of the family activism index (FAI) captures the degree of activism on the part of family shareholders in relation to the generation running the business, such that GFF has a value of 2 if the family shareholder belongs to the first generation, 1.5 if to the second and 1 if to the third and subsequents.

The family activism index, FAI, captures the closer control exercised by family shareholders. We assume, furthermore, that there will be significant capacity to exercise this control when the family shareholder holds $10 \%$ or more of the shares. The index will therefore have a value between 0 and 1 . After removing any observations where all of the variables required for the estimation of the leverage and economic value creation equations are not present, the median value of the activism index $(0.66)$ is calculated for the whole sample and used in phase three of the study to segment the sample firms by high and low family activism indices.

Previous studies on family business transitions in different countries (Sonfield, Lussier 2004; Sonfield et al. 2005) enable us to propose a formula for determining the approximate length of the family firm lifecycle (DLFF) ${ }^{9}$.

\footnotetext{
${ }^{8}$ This index was developed from Bobillo et al. (2009).

${ }^{9}$ See Bobillo et al. (2013).
} 


\subsection{Methodology}

The first of the relationships to be examined relates to the scope of internationalization, which we explain by regressing the number of countries to which the firm exports (Is) on to the family activism index (FAI) and life cycle duration (DLFF) in a simple linear regression.

Since we also aim to check for possible simultaneity between debt financing (LEV) and economic value creation (ROA), it seems appropriate to use a system of simultaneous equations, with one equation for each variable of interest. Thus, the first equation incorporates the determinants of debt financing and the second the determinants of economic value creation.

Following standard practice in the research on debt financing decisions, we consider capital structure to be a function of firm size; firm profitability; the degree of ownership concentration; the structure of collateral assets in the event of loan default or for the solution of potential asset substitution problems; the point reached in the business lifecycle; and the sector of activity. The determinants considered with regard to economic value creation are leverage, size, ownership concentration, growth opportunities, economic potential, current point in the business lifecycle, investment opportunities, and the firm's sector of activity.

Thus, the equations take the following form:

$$
\begin{aligned}
& \text { Is }=\alpha+\beta 1 . F A I+\beta 2 . D L F F+\varepsilon_{i t}, \\
& \mathrm{LEV}_{\text {it }}=\alpha+\beta 1 . \mathrm{ROA}_{\mathrm{it}}+\beta 2 . \mathrm{C5}_{\mathrm{it}}+\beta 3 . \mathrm{NLSALES}_{\mathrm{it}}+\beta 4 . \mathrm{INCSALES}_{\mathrm{it}}+ \\
& \beta 5 . \text { PINTANG }_{i t}+\beta 6 . \text { DLFF }_{i t}+\sum \gamma_{\mathrm{j}} \text { INDUSTRY }_{\mathrm{j}}+\varepsilon_{\mathrm{i}} \text {, } \\
& \mathrm{ROA}_{\mathrm{it}}=\alpha+\beta 1 . \mathrm{LEV}_{\mathrm{it}}+\beta 2 . \mathrm{C5}_{\mathrm{it}}+\beta 3 . \mathrm{NLSALES}_{\mathrm{it}}+\beta 4 . \mathrm{INCSALES}_{\mathrm{it}}+ \\
& \text { B5.EP } \text { it }+\beta 6 . \text { DLFF }_{i t}+\text { B7.IO }_{i t}+\sum \gamma_{\mathrm{j}} \text { INDUSTRY }_{\mathrm{j}}+\varepsilon_{\mathrm{it}} \cdot
\end{aligned}
$$

Our first test involves the relationship between the scope of internationalization in FFs and its two explanatory variables FAI and DLFF. Our second, given the possible differences in family firms, i.e., multinational versus domestic, and high versus low family activism, our aim is to analyze whether the relationship between leverage and economic value creation and the explanatory variables is different in each subsample. We therefore estimate the system of equations in a different way in each case.

Estimations in this second phase of the analysis are performed using the three-step least squares method (MC3E), which provides greater efficiency than more traditional methods, such as two-step least squares estimation, when there are correlations between the error terms of the various equations. Leverage and economic value creation are used as the endogenous variables.

\section{Results}

Table 3 shows the data obtained from the regression of the number of countries to which a firm is exporting against the degree of family activism and life cycle duration in FFs. The relationship in both cases is positive and significant. This confirms our first 
Table 3. Results of the regression model for scope of internationalization

\begin{tabular}{|c|c|}
\hline Dependent Variable: N.C & \\
\hline FAI & $\begin{array}{c}2.3598 \\
(0.015)^{* *}\end{array}$ \\
\hline DLFF & $\begin{array}{c}0.3157 \\
(0.000)^{* * *}\end{array}$ \\
\hline Cons & $\begin{array}{c}-3.6215 \\
(0.000)^{* * *}\end{array}$ \\
\hline $\mathrm{R} 2$ & 0.0564 \\
\hline $\mathrm{F}(2.7377)$ & $\begin{array}{c}240.41 \\
(0.000)^{* * *}\end{array}$ \\
\hline
\end{tabular}

Notes: Coefficients estimated and $\mathrm{P}>|\mathrm{z}|$ (between parentheses): ***,**, *: significant at $1 \%, 5 \%$, and $10 \%$. For variables definition see Annex I.

hypothesis, H1, that the scope of internationalization in FFs is determined both by the degree of family activism and by the stage the firm has reached in its lifecycle. The $\mathrm{F}$ statistic indicates joint statistical significance.

Table 4 shows the results of the simultaneous equation regressions of leverage and economic value creation on the two subsets of explanatory variables for the multinational and domestic FF subsamples.

As far as the individual hypotheses are concerned, there is a positive linear relationship between LEV and C5 for both multinational and domestics FF and between LEV and PINTANG which partially confirms our second hypothesis, H2. DLFF has a significant negative influence on economic value creation in both multinational FFs and domestic FFs, which partially confirms our third hypothesis, H3, since, contrary to expectations, it has a negative influence on leverage in domestic FFs. Other relationships worth noting are the negative influence of leverage on economic value creation, the positive influence of size on debt financing in both multinational and domestic FFs, and the negative influence of investment opportunities in domestic FFs. The simultaneous equation estimates proved to be highly significant for economic value creation equation in both subsamples and for leverage in the multinational subsample.

Table 5 presents the simultaneous equation estimates for the high/low family activism subsamples. The simultaneity of the estimation enables us to observe that, while economic value creation has a positive influence on the degree of leverage the influence of leverage on economic value creation is negative. Both these relationships are significant only for the high FAI subsample. Innovation capability proves to be significant and positive in the leverage equation, but, as predicted by hypothesis 4 , only in association with high family activism. This is precisely the kind of firm in which growth opportunities, which is positively signed, and length of lifecycle and investment opportunities, both negatively signed, provide the basis of the capacity for economic value creation. 
Table 4. Results from the simultaneous equations model. Multinational FFs vs. domestic FFs

\begin{tabular}{|c|c|c|}
\hline & Multinational FFs & Domestic FFs \\
\hline \multicolumn{3}{|c|}{ DEP .Var. : Lev } \\
\hline roa & $\begin{array}{c}5.5518 \\
(0.2)\end{array}$ & $\begin{array}{l}5.8853 \\
(0.109)\end{array}$ \\
\hline $\mathrm{c} 5$ & $\begin{array}{c}0.1525 \\
(0.053)^{*}\end{array}$ & $\begin{array}{c}0.1277 \\
(0.048)^{* *}\end{array}$ \\
\hline nlsales & $\begin{array}{c}-0.032 \\
(0.248)\end{array}$ & $\begin{array}{l}-0.004 \\
(0.723)\end{array}$ \\
\hline incsales & $\begin{array}{l}-0.020 \\
(0.326)\end{array}$ & $\begin{array}{l}0.0014 \\
(0.653)\end{array}$ \\
\hline pintang & $\begin{array}{c}0.5762 \\
(0.155)\end{array}$ & $\begin{array}{c}0.8096 \\
(0.062)^{*}\end{array}$ \\
\hline DLFF & $\begin{array}{c}0.0954 \\
(0.32)\end{array}$ & $\begin{array}{c}-0.141 \\
(0.001)^{* * *}\end{array}$ \\
\hline cons & $\begin{array}{l}0.0294 \\
(0.955) \\
\end{array}$ & $\begin{array}{r}-0.542 \\
(0.51)\end{array}$ \\
\hline INDUSTRY & NO & NO \\
\hline $\mathrm{Chi}^{2}$ & $\begin{array}{c}24.23 \\
(0.0291)^{* *}\end{array}$ & $\begin{array}{c}10.70 \\
(0.7095)\end{array}$ \\
\hline \multicolumn{3}{|c|}{ Dep. VAR. : roa } \\
\hline lev & $\begin{array}{l}-1.012 \\
(0.118)\end{array}$ & $\begin{array}{c}-0.501 \\
(0.018)^{* *}\end{array}$ \\
\hline $\mathrm{c} 5$ & $\begin{array}{l}0.0477 \\
(0.282)\end{array}$ & $\begin{array}{l}0.0159 \\
(0.321)\end{array}$ \\
\hline nlsales & $\begin{array}{c}0.0058 \\
(0.083)^{*}\end{array}$ & $\begin{array}{c}0.0053 \\
(0.028)^{* *}\end{array}$ \\
\hline incsales & $\begin{array}{l}0.0054 \\
(0.259)\end{array}$ & $\begin{array}{l}0.0010 \\
(0.165)\end{array}$ \\
\hline ep & $\begin{array}{l}-0.000 \\
(0.333)\end{array}$ & $\begin{array}{l}0.0000 \\
(0.934)\end{array}$ \\
\hline DLFF & $\begin{array}{c}-0.044 \\
(0.02)^{* *}\end{array}$ & $\begin{array}{c}-0.071 \\
(0.029)^{* *}\end{array}$ \\
\hline io & $\begin{array}{l}-0.000 \\
(0.108)\end{array}$ & $\begin{array}{c}-0.000 \\
(0.007)^{* * *}\end{array}$ \\
\hline cons & $\begin{array}{l}0.7900 \\
(0.08)^{*}\end{array}$ & $\begin{array}{c}0.5313 \\
(0.029)^{* *}\end{array}$ \\
\hline INDUSTRY & YES & NO \\
\hline $\mathrm{Chi}^{2}$ & $\begin{array}{c}26.75 \\
(0.0207)^{* *}\end{array}$ & $\begin{array}{c}38.17 \\
(0.0009)^{* * *}\end{array}$ \\
\hline
\end{tabular}

Notes: Coefficients estimated and $\mathrm{P}>|\mathrm{z}|$ (between parentheses): ***,**, *: significant at $1 \%, 5 \%$, and $10 \%$. For variables definition see Annex I. 
Table 5. Results from the simultaneous equations model. FFs with high vs. low Family Activism Indices

\begin{tabular}{|c|c|c|}
\hline & FFs with high FAI & FFs with low FAI \\
\hline \multicolumn{3}{|c|}{ DEP. VAR.: Lev } \\
\hline Roa & $\begin{array}{c}6.4978 \\
(0.004)^{* * *} \\
\end{array}$ & $\begin{array}{l}7.4959 \\
(0.203)\end{array}$ \\
\hline $\mathrm{c} 5$ & $\begin{array}{l}0.1296 \\
(0.164)\end{array}$ & $\begin{array}{l}0.0899 \\
(0.226)\end{array}$ \\
\hline nlsales & $\begin{array}{l}-0.008 \\
(0.371) \\
\end{array}$ & $\begin{array}{l}-0.029 \\
(0.272) \\
\end{array}$ \\
\hline incsales & $\begin{array}{c}0.0011 \\
(0.701)\end{array}$ & $\begin{array}{c}-0.005 \\
(0.83)\end{array}$ \\
\hline pintang & $\begin{array}{c}0.7999 \\
(0.004)^{* * *}\end{array}$ & $\begin{array}{l}0.4720 \\
(0.302)\end{array}$ \\
\hline dlff & $\begin{array}{l}0.0269 \\
(0.536) \\
\end{array}$ & $\begin{array}{l}0.0317 \\
(0.752) \\
\end{array}$ \\
\hline cons & $\begin{array}{l}-0.598 \\
(0.224) \\
\end{array}$ & $\begin{array}{c}0.7857 \\
(0.069)^{*} \\
\end{array}$ \\
\hline INDUSTRY & YES & NO \\
\hline Chi2 & $\begin{array}{c}32.40 \\
(0.0021)^{* * *}\end{array}$ & $\begin{array}{c}36.19 \\
(0.0010)^{* * *}\end{array}$ \\
\hline \multicolumn{3}{|c|}{ Dep. VAR.: roa } \\
\hline lev & $\begin{array}{c}-0.593 \\
(0.002)^{* * *}\end{array}$ & $\begin{array}{l}-0.897 \\
(0.534)\end{array}$ \\
\hline $\mathrm{c} 5$ & $\begin{array}{l}0.0162 \\
(0.439)\end{array}$ & $\begin{array}{l}0.0434 \\
(0.585)\end{array}$ \\
\hline NLSALES & $\begin{array}{l}0.0022 \\
(0.211)\end{array}$ & $\begin{array}{l}-0.000 \\
(0.971)\end{array}$ \\
\hline INCSALES & $\begin{array}{c}0.0013 \\
(0.063)^{*} \\
\end{array}$ & $\begin{array}{l}0.0155 \\
(0.467) \\
\end{array}$ \\
\hline EP & $\begin{array}{l}-0.000 \\
(0.262)\end{array}$ & $\begin{array}{l}0.0000 \\
(0.901)\end{array}$ \\
\hline DLFF & $\begin{array}{c}-0.038 \\
(0.001)^{* * *} \\
\end{array}$ & $\begin{array}{l}-0.087 \\
(0.455)\end{array}$ \\
\hline IO & $\begin{array}{c}-0.000 \\
(0.000)^{* * *}\end{array}$ & $\begin{array}{l}-0.000 \\
(0.488)\end{array}$ \\
\hline CONS & $\begin{array}{c}0.6590 \\
(0.000)^{* * *} \\
\end{array}$ & $\begin{array}{l}0.6071 \\
(0.345) \\
\end{array}$ \\
\hline INDUSTRY & YES & No \\
\hline Chi2 & $\begin{array}{c}11.88 \\
(0.6159)\end{array}$ & $\begin{array}{c}12.53 \\
(0.6388)\end{array}$ \\
\hline
\end{tabular}

Notes: Coefficients estimated and $\mathrm{P}>|\mathrm{z}|$ (between parentheses): ***,**, *: significant at $1 \%, 5 \%$, and $10 \%$. For variables definition see Annex I. 


\section{Discussions and conclusions}

In this paper, we have analyzed the effect of ownership structure and family activism (FAI) on leverage, economic value creation and international diversification in the family firm. To enrich the analysis, we included additional explanatory variables, such as the capacity to exploit intangible assets and the capacity to generate and exploit growth opportunities, among others. Together with ownership concentration, we also analyzed DLFF (the lifecycle duration) and the FAI as basic determinants of economic value creation and international diversification in FFs.

Our review of previous research suggested that, as well as ownership structure, other variables associated with the exploitation of intangible assets (capacity to innovate, capacity to detect growth opportunities), DLFF, and family activism may provide the foundational pillars for economic value creation, survival, and international diversification in FFs.

The results of our study largely confirm the hypotheses that we have tested. Firstly, we find that there is a linear relationship in family firms between the scope of internationalization and the variables for family activism and DLFF. This appears to indicate that a certain degree of family activism (which increases the level of information asymmetry) drives managers towards expansion into foreign markets in an attempt to escape from over-controlling family shareholders and to diversify risk. The successive generations running the FF may be less risk averse when it comes to seeking new opportunities to create economic value and raise capital. The DLFF (especially at the firm maturity stage) is another significant variable that could be capturing the importance of previous generations' accumulated knowledge of foreign markets and greater ability to assess the potential risk factors involved.

Secondly, by splitting the FF sample into multinationals and non-multinationals, in the search for differences, we find that ownership structure and the exploitation of intangible assets (the main competitive advantage of FFs) have a positive effect on leverage and economic value creation in both these subsamples. However, the DLFF presents a negative impact on economic value creation. A possible explanation for this could be that the generation running the business initially pursues not short-term growth in foreign markets but rather firm survival. This objective is more compatible with the tendency of FFs to sacrifice short-term growth in favor of long-term objectives. The positive effect on leverage can be explained by the fact that the successive generations running the $\mathrm{FF}$ are increasingly reluctant to resort to debt in order to finance international expansion, and sometimes prefer to finance it through share issues, provided they see no danger of losing firm control.

Thirdly, we find evidence of the important role played by family activism in strengthening the effects of ownership structure, incentives, the exploitation of intangible assets and the generation of growth opportunities on leverage and economic value creation in FFs. One explanation for this effect is that it is basically due to major barriers (high opportunity costs) preventing large-block family shareholders from withdrawing capital and investing it elsewhere. 
In conclusion, economic value creation, debt financing and international diversification in FFs do not depend simply on ownership concentration and firm size, since the evidence also shows that the exploitation of intangible assets, the generation of growth opportunities, the DFLL (especially in the firm maturity stage) and family activism are the keys to enable FFs to face their current challenges.

\section{Limitations and directions for future research}

Despite the conclusiveness of our findings, this study has some limitations that will need to be taken into account in future research. One is that the sample for this study consisted exclusively of family firms in Spain, a country whose financial system is mainly bank-oriented. Extension of the sample to include FFs from countries such as the UK, Canada or the USA, whose financial systems are oriented towards the stock market would lead to more widely applicable results.

One direction for future research would be to examine variability of FF behavior in relation to value creation at different levels of family activism in bank-oriented economies (less protection for minority shareholders) versus market-oriented economies (greater protection for minority shareholders). It would also be interesting to analyze the joint impact of the generation running the business and stage reached in the firm's lifecycle on economic value creation in FFs.

Our family activism index was constructed taking into account only ownership concentration and the generation running the business (GFF). The incorporation of a variable to capture whether or not the owner-manager is also the major shareholder would increase the generalizability and measuring validity of this scale.

Similarly, it would be useful to distinguish between leveraged ownership (employeeowners; service-provider-owners) and non-leveraged ownership (shareholder only) with a view to comparing the different aims of each type of owner.

\section{References}

Adams, R.; Almeida, H.; Ferreira, D. 2004. Understanding the relationship between founderCEOs and firm performance, Working paper. New York University.

Alchian, A. A.; Demsetz, H. 1972. Production, information costs, and economic organization, American Economic Review 62(5): 777-795.

Ansari, S. L.; Bell, J. 1991. Symbolism, collectivism and rationality in organisational control, Auditing and Accounting Journal 4(2): 4-27.

Beckhard, R.; Dyer, W. 1983. Managing continuity in family-owned business, Organizational Dynamics 12(1): 5-12. http://dx.doi.org/10.1016/0090-2616(83)90022-0

Berle, A. A. Jr.; Means, G. C. 1932. The modern corporation and private property. New York: Macmillan.

Björnberg, A.; Nicholson, N. 2007. The family climate scales-development of a new measure for use in family business research, Family Business Review 20(3): 229-246.

http://dx.doi.org/10.1111/j.1741-6248.2007.00098.x

Bobillo, A. M.; Rodriguez-Sanz, J. A.; Tejerina-Gaite, F. 2009. Investment decisions, liquidity and institutional activism: an international study, Journal Business Ethics 87: 25-40.

http://dx.doi.org/10.1007/s10551-008-9798-9 
Bobillo, A. M.; Rodriguez-Sanz, J. A.; Tejerina-Gaite, F. 2013. Leverage, economic value creation and life cycle in family firm, European Journal of International Management, forthcoming. Boston Consulting Group. 1994. Shareholder value management: improved measurement drives improved value creation, Booklet 2. Boston.

Boston Consulting Group. 1995. Shareholder value management, Booklet 2. Chicago.

Burkart, M.; Panunzi, F.; Shleifer, A. 2003. Family firms, Journal of Finance 58(5): 2167-2202. http://dx.doi.org/10.1111/1540-6261.00601

Camelo-Ordaz, C.; Hernandez-Lara, A. B.; Valle-Cabrera, R. 2005. The relationship between top management teams and innovative capacity in companies, Journal of Management Development 24(8): 683-705. http://dx.doi.org/10.1108/02621710510613726

Carr, J. C.; Haggard, S. K.; Himieleski, K. M.; Zahra, S. A. 2010. A study of the moderating effects of firm age at internationalization on firm survival and short-term growth, Strategic Entrepreneurship Journal 4(2): 183-192. http://dx.doi.org/10.1002/sej.90

Crick, D.; Jones, M. V. 2000. Small high-technology firms and international high-technology markets, Journal of International Marketing 8(2): 63-76. http://dx.doi.org/10.1509/jimk.8.2.63.19623

David, P.; Hitt, M. A.; Gimeno, J. 2001. The role of institutional investors in influencing R\&D, Academy of Management Journal 44: 144-157. http://dx.doi.org/10.2307/3069342

Demsetz, H. 1983. The structure of ownership and the theory of the firm, Journal of Law and Economics 26(2): 375-390. http://dx.doi.org/10.1086/467041

Driffield, N.; Mahambre, V.; Pal, S. 2004. How does ownership affect capital structure and firm value? Recent evidence from East Asia, Working paper no 7. Centre for Economic Development \& Institutions, Brunel University, West London.

Dunn, T.; Holtz-Eakin, D. 2000. Financial capital, human capital, and the transition to selfemployment: evidence from intergenerational links, Journal of Labor Economics18(2): 282-305. http://dx.doi.org/10.1086/209959

Dyer, W. G. 1988. Integrating professional management into a family owned business, Family Business Review 2: 221-235. http://dx.doi.org/10.1111/j.1741-6248.1989.00221.x

Eriksson, K.; Johanson. J.; Majkgard, A.; Sharma, D. 1997. Effect of variation on knowledge accumulation in the internationalization process, International Studies of Management \& Organization 30(1): 26-44.

Fatemi, A. M. 1984. Shareholder benefits from corporate international diversification, Journal of Finance 39(5): 1325-1343. http://dx.doi.org/10.1111/j.1540-6261.1984.tb04910.x

Friend, I.; Lang, L. 1988. An empirical test of the impact of managerial self-interest on corporate capital structure, Journal of Finance 43(2): 271-281.

http://dx.doi.org/10.1111/j.1540-6261.1988.tb03938.x

Gosselin, M. 1997. The effect of strategy and organizational structure on the adoption and implementation of activity-based costing, Accounting, Organization and Society 22(2): 105-122. http://dx.doi.org/10.1016/S0361-3682(96)00031-1

Johanson, J.; Vahlne. J.-E. 1977. The internationalization process of the firm - a model of knowledge development and increasing foreign market commitments, Journal of International Business Studies 8(1): 23-32. http://dx.doi.org/10.1057/palgrave.jibs.8490676

Lacuesta, A.; Licandro, O.; Molina, T.; Puch, L. A. 2009. Innovation, tangible and intangible investments and the value of Spanish firms, Working paper no 19. Fundación Estudios Economía Aplicada, Madrid.

Lane, S.; Astrachan, J.; Keyt, A.; McMillan, K. 2006. Guidelines for family business boards of directors, Family Business Review 19(2): 147-167.

http://dx.doi.org/10.1111/j.1741-6248.2006.00052.x 
Leach, P.; Bogod, T. 1999. Guide to the family business, 3rd ed. Pentonville Road, London: Kogan Page Publishers.

Lee, H. J.; Park, J. H. 2006. Top team diversity, internationalization and the mediating effect of international alliances, British Journal of Management 17(3): 195-213.

http://dx.doi.org/10.1111/j.1467-8551.2006.00501.x

Lentz, B.; Laband, D. 1990. Entrepreneurial success and occupational inheritance among proprietors, Canadian Journal of Economics 23(3): 563-579. http://dx.doi.org/10.2307/135648

Lewellen, W. 1971. A pure financial rationale for the conglomerate merger, Journal of Finance 26(2): 521-537. http://dx.doi.org/10.1111/j.1540-6261.1971.tb00912.x

Lussier, R. N.; Sonfield, M. 2010. A six-country study of first-, second-, and third-generation family business, International Journal of Entrepreneurial Behaviour \& Research 16(5): 414-436. http://dx.doi.org/10.1108/13552551011071869

Madsen, T. K.; Servais, P. 1997. The internationalization of born globals: an evolutionary process?, International Business Review. 6(6): 561-583. http://dx.doi.org/10.1016/S0969-5931(97)00032-2

Marsh, P. 1982. The choice between equity and debt: an empirical study, Journal of Finance 37(1): 121-144. http://dx.doi.org/10.1111/j.1540-6261.1982.tb01099.x

Martin, J. D.; Petty, J. W. 2001. Value based management. The corporate response to the shareholder revolution. USA: Oxford University Press.

Martin, J. D.; Petty, J. W.; Steven, P. R. 2003. An analysis of EVA and other measures of firm performance based on residual income [online], [cited 2011]. Available from Internet: http://ssrn. com/abstract $=412122$.

Moreno, J.; Castillo, L.; Masere, E. 2010. Firm size and entrepreneurial characteristics: evidence from the SME sector in Argentina, Journal of Business Economics and Management 11(2): 259-282. http://dx.doi.org/10.3846/jbem.2010.13

Moreno, J.; Castillo, L. 2011. Corporate growth, age and ownership structure: empirical evidence in Spanish firms, Journal of Business Economics and Management 12(1): 164-196.

http://dx.doi.org/10.3846/16111699.2011.555449

Peng, N. W.; Tan, J.; Tong, T. W. 2004. Ownership types and strategic groups in an emerging economy, Journal of Management Studies 41(7): 1105-1129.

http://dx.doi.org/10.1111/j.1467-6486.2004.00468.x

Rajan, R.; Zingales, L. 1995. What do we know about capital structure? Some evidence from international data, Journal of Finance 50(5): 1421-1460.

http://dx.doi.org/10.1111/j.1540-6261.1995.tb05184.x

Randoy, T.; Dibrell, C. 2004. Founding family leadership, product market competition, and firm performance among publicly traded firms, in 2004 FMA European Conference Program, 2-4 June, 2004, Zurich, Switzerland.

Sharma, P.; Rao, A. 2000. Successor attributes in Indian \& Canadian family firms: a comparative study, Family Business Review 13(4): 313-330.

http://dx.doi.org/10.1111/j.1741-6248.2000.00313.x

Shleifer, A.; Vishny, R. W. 1997. A survey of corporate governance, Journal of Finance 52(2): 737-783. http://dx.doi.org/10.1111/j.1540-6261.1997.tb04820.x

Sirmon, D. G.; Hitt, M. A. 2003. Managing resources: linking unique resources, management and wealth creation in family firms, Entrepreneurship Theory and Practice 27(4): 339-358.

http://dx.doi.org/10.1111/1540-8520.t01-1-00013

Sonfield, M. C.; Lussier, R. N. 2004. First, second and third-generation family firms: a comparison, Family Business Review 17: 189-202. http://dx.doi.org/10.1111/j.1741-6248.2004.00013.x 
Sonfield, M.; Lussier, R.; Pfeifer, S.; Manikutty, S.; Maherault, L.; Verdier, L. 2005. A crossnational investigation of first-generation, second-generation and third-generation family businesses, Journal of Small Business Strategy 16(1): 9-26.

Thomsen, S.; Pedersen, T. 2000. Ownership structure and economic performance in the largest European companies, Strategic Management Journal 21(6): 689-705.

http://dx.doi.org/10.1002/(SICI)1097-0266(200006)21:6<689::AID-SMJ115>3.0.CO;2-Y

Upton, N.; Teal, E. J.; Felan, J. T. 2001. Strategic and business planning practices of fast-growth family firms, Journal of Small Business Management 39(1): 60-72.

http://dx.doi.org/10.1111/0447-2778.00006

Villalonga, B.; Amit, R. 2008. Family control of firms and industries, Working paper. Harvard University.

Westhead, P. M.; Wright, M.; Ucbasaran, D. 2001. The internationalization of new and small firms: a resource based view, Journal of Business Venturing 16(4): 333-358.

http://dx.doi.org/10.1016/S0883-9026(99)00063-4

Wiersema, M. F.; Bantel, K. A. 1992. Top management team demography and corporate strategic change, Academy of Management Journal 35(1): 91-121. http://dx.doi.org/10.2307/256474

Yang, W. 2005. Corporate investment and value creation, SSRN Working paper Ref. 44.

Zahra, S. A. 2005. Entrepreneurial risk taking in family firms, Family Business Review 18(1): 23-40. p://dx.doi.org/10.1111/j.1741-6248.2005.00028.x

Zahra, S. A.; Ireland, R. D.; Hitt, M. A. 2000. International expansion by new venture firms: international diversity, mode of market entry, technological learning, and firm performance, Academy of Management Journal 43(5): 925-950. http://dx.doi.org/10.2307/1556420

Zellweger, T. 2007. Time horizon, costs of equity capital, and generic investment strategies of firms, Family Business Review 20(1): 1-15. http://dx.doi.org/10.1111/j.1741-6248.2007.00080.x 


\section{APPENDIX A. Definition of variables}

\begin{tabular}{|c|c|}
\hline Variable & Definition of variables measures based on prior studies \\
\hline $\begin{array}{l}\text { Leverage } \\
\text { (LEV) }\end{array}$ & $\begin{array}{l}\text { Ratio of total debt to total assets } \\
\text { Lewellen (1971) }\end{array}$ \\
\hline $\begin{array}{l}\text { Economic value creation } \\
\text { (ROA) }\end{array}$ & $\begin{array}{l}\text { Ratio of profits before interest and tax to total assets. } \\
\text { Boston Consulting Group (1994, 1995), Martin and Petty } \\
\text { (2001), Martin et al. (2003), Zellweger (2007) }\end{array}$ \\
\hline $\begin{array}{l}\text { Ownership concentration } \\
\text { (C5) }\end{array}$ & $\begin{array}{l}\text { Summed percentage of shares controlled by top five shareholders } \\
\text { Randoy and Dibrell (2004) }\end{array}$ \\
\hline $\begin{array}{l}\text { Firm size } \\
(\text { NLSALES) }\end{array}$ & $\begin{array}{l}\text { Neperian log of total sales volume } \\
\text { Marsh (1982), Friend and Lang (1988), Rajan } \\
\text { and Zingales (1995) }\end{array}$ \\
\hline $\begin{array}{l}\text { Growth opportunities } \\
\text { (INCSALES) }\end{array}$ & $\begin{array}{l}\text { Increase in sales between } \mathrm{t} \text { and } \mathrm{t}-1 \text { divided by total sales } \\
\text { volume at } \mathrm{t}-1 \\
\text { Marsh (1982), Friend and Lang (1988), Rajan } \\
\text { and Zingales (1995) }\end{array}$ \\
\hline $\begin{array}{l}\text { Innovation potential } \\
\text { (PINTANG) }\end{array}$ & $\begin{array}{l}\text { Ratio of intangible assets to total assets } \\
\text { Gosselin (1997), Lacuesta et al. (2009) }\end{array}$ \\
\hline $\begin{array}{l}\text { Lifecycle duration } \\
\text { (DLFF) }\end{array}$ & $\begin{array}{l}\text { Neperian log of age } \\
\text { Driffield et al. (2004) }\end{array}$ \\
\hline $\begin{array}{l}\text { Sector of activity } \\
\text { (INDUSTRY) }\end{array}$ & $\begin{array}{l}\text { Dummy variable that takes a value of } 1 \text { if the firm } \\
\text { belongs to sector } \mathrm{J} \\
\text { Driffield et al. (2004) }\end{array}$ \\
\hline $\begin{array}{l}\text { Economic potential } \\
\text { (EP) }\end{array}$ & $\begin{array}{l}\text { Increase in volume of fixed assets between } t \text { and } t-1 \text { plus } \\
\text { depreciation costs of fixed assets divided by the volume } \\
\text { of fixed assets at } t-1 \\
\text { Lacuesta et al. (2009) }\end{array}$ \\
\hline $\begin{array}{l}\text { Investment opportunities } \\
\text { (IO) }\end{array}$ & $\begin{array}{l}\text { Ratio of total assets to total sales } \\
\text { Yang (2005) }\end{array}$ \\
\hline $\begin{array}{l}\text { Family activism index } \\
\text { (FAI) }\end{array}$ & $\begin{array}{l}\text { Capacity and frequency of shareholder control and monitoring } \\
\text { over managers in FF }\end{array}$ \\
\hline $\begin{array}{l}\text { Scope internationalization } \\
\left(I_{\mathrm{s}}\right)\end{array}$ & Number of countries which the firm is exporting \\
\hline
\end{tabular}

Alfredo M. BOBILLO (PhD) is a Professor of International Business at the University of Valladolid (Spain). He teaches Business and Finance at the University of Valladolid. He has been Visiting Research Fellow at Uppsala University and Stockholm School of Economics (SE). He has published widely in various refereed national and international journals.

Juan A. RODRÍGUEZ-SANZ $(\mathrm{PhD})$ is an Associate Professor of Finance at the University of Valladolid (Spain). He teaches Finance, Corporate Governance and Financial Management at the University of Valladolid. He has published widely in various refereed journals.

Fernando TEJERINA-GAITE $(\mathrm{PhD})$ is an Associate Professor of Finance at the University of Valladolid (Spain). He teaches Finance and Corporate Governance at the University of Valladolid. He has been Visiting Research Fellow at the Leeds Business School (UK). He research and publications are in the areas of international finance, family business, financial economics. 